\title{
On the Road to Disaster: Strategic Misalignments and Corporate Failure
}

\author{
Loizos Heracleous, Katrin Werres
}

Prior research has identified the link between strategic misalignment and corporate failure, but little empirical research to date has examined the process leading to misalignment and eventual corporate failure over time. To explore this crucial link, we conducted indepth case studies of two American conglomerates: WorldCom and Nortel Networks. We find patterns in terms of factors through which misalignments develop, ultimately leading to bankruptcy. The process begins with dysfunctional leadership and ineffective corporate governance, moving to unduly risky strategic actions, which are then followed by lax execution. Gradually spreading organizational misalignments develop, which ultimately foster a large gap between the demands of the competitive environment and the organization's strategy and competencies, leading to failure. An unforgiving external environment exacerbates the effects of misalignments. With this study, we also expand the ESCO strategic alignment model (Environment, Strategy, Core Competencies, and Organization), by adding leadership as the actor guiding alignment, and sustainable advantage as an outcome.

(C) 2015 Elsevier Ltd. All rights reserved.

\section{Introduction}

Corporate bankruptcy rates have soared. Between 2007 and 2010, total bankruptcy rates rose by 87.2\% (Flynn and Kearns, 2011). Among the bankrupt organizations in recent years were numerous multinationals, once healthy and leading corporations such as General Motors, Delphi, Tribune Group, Conseco and Chrysler. Why do so many previously highly successful firms fail? Organizational failure can be brought about by strategic misalignments; e.g., an inappropriate strategy for the external environment, or a poor operationalization of the strategy. Strategic alignment is the consistency and synergy among the external environment, the strategy, core competencies, and organizational elements such as culture, organization design, processes and people (Heracleous et al., 2009). Conversely, strategic misalignment is inconsistency or tension among these elements.

Whereas the link between strategic alignment and competitive advantage (and conversely misalignment and failure) has been recognized (Beer et al., 2005; Miles and Snow, 1984a; Powell, 1992) the processes of how strategic misalignments can develop over time and lead to corporate failure have not yet been explored. Despite their valuable contributions, most studies on corporate failure have adopted a fairly static orientation, rather than a time-sensitive, processual perspective of how a corporation can move towards failure (Zajac et al., 2000). In light of environmental dynamism, and the insights that can be afforded by a longer-term examination, scholars have called for research that examines fit and alignment "within a longitudinal perspective" (Venkatraman, 1989, 441). In our research, we take such a perspective and examine how misalignments can develop over time, ultimately leading to corporate failure.

Are there typical patterns of strategic misalignments? What are the processes that can lead to failure if left unchecked, and can we identify factors leading towards failure? We explore these questions by applying a strategic alignment perspective that examines the interrelated levels of environment, strategy, competencies and organization (Heracleous et al., 2009). We begin with a discussion of the literature relating to strategic alignment and corporate failure. We then outline our research methodology and provide a brief background of the case studies, followed by the case analysis and findings. The analysis involves individual as well as cross-case analysis, upon which we develop a model of decline and failure. We then conclude with a discussion and contributions.

We identified six interrelated factors of strategic misalignment, whereby, the first three mark the most significant antecedents leading to corporate failure. Once strategic misalignments are established at one organizational level, further misalignments expand from this level to various other areas inside the organization. In the latter stages, significant gaps are created between the strategy and competencies of the firm, and between strategy and the demands of the competitive environment, which leads to corporate failure. 


\section{Strategic alignment and performance}

It has been recognized that several factors can influence a firm's performance. These include external factors such as changes in the industry and environmental uncertainty, as well as internal factors such as coordination and control, age, size, corporate culture and leadership (Anderson and Tushman, 2001; Fredrickson, 1986; Freeman et al., 1983). An alignment perspective attempts to interrelate such factors both internally within an organization, and between an organization and its environment. The logic is that internal organizational alignment or fit, as well as alignment with the external environment, are necessary requirements for any firm to ensure survival and success in the long run (Beer et al., 2005; Miles and Snow, 1984a; Porter, 1996). A distinction between descriptive and normative fit has been made, where the former is mostly concerned with description of the existing situation without explicit reference to performance, and the latter explicitly focuses on the alignment-performance relationship (Venkatraman, 1989).

Within strategic management, the alignment approach grounded in industrial economics or contingency theory is referred to as an "outside-in approach" (Voelpel et al., 2006). Strategy and structure are viewed here as being a response to external factors, which act as key determinants of the firm's performance (Ginsberg and Venkatraman, 1985; Porter, 1980; Venkatraman and Camillus, 1984). In contrast, the resource-based view, referred to as an "inside-out approach" (Voelpel et al., 2006), emphasizes internal elements such as resources and capabilities as routes to competitive advantage (Barney, 1991; Grant, 1991; Wernerfelt, 1984). Despite contrasting perspectives on directionality, both schools of thought concur that strategic alignment can lead to sustainable competitive advantage and, conversely, misalignment can lead to failure (Chabrak and Daidj, 2007; Miller, 1996; Porter, 1996; Powell, 1992). Holistic models of strategic alignment have endeavored to incorporate several interrelated factors. Such frameworks include the classic McKinsey 7-S model (Waterman et al., 1980), as well as the more recent ESCO model (Heracleous et al., 2009).

We discuss domains of alignment along the lines of the ESCO model (Environment, Strategy, Core Competencies and Organization) (Heracleous et al., 2009). This model suggests that a company's strategy has to be aligned with its competitive environment. It also has to be supported by appropriate core competencies, which can be delivered through suitable organizational configurations (including culture, structure, processes and people). Figure 1 below shows the ESCO model.

\section{Four domains of (Mis)alignment: environment, strategy, core competencies and organization}

With regard to environmental change, firms are faced with discontinuity and rapid changes caused by technological development, disruptive innovations, intense global competition, alterations in governmental regulations, and shifts in industry structures (Beer et al., 2005; Crossan et al., 2008). Many market environments have reached unprecedented levels of complexity, uncertainty and dynamism (Ireland and Hitt, 2005). While in the past, due to comparatively stable market conditions, alignment among a firm's strategy and external environment was easier to achieve, the dynamics have become significantly more challenging. A firm's insufficient realignment to drastic environmental changes represents one of the most common and dangerous sources of misalignment in organizations (Heracleous et al., 2009).

The second alignment element, strategy, includes the classic classifications proposed by Porter (1985), Hannan and Freeman (1986) and Miles et al. (1978), who emphasize the need for clear strategic choices. Dynamic views of strategy recognize that competitive advantage is fleeting, constant realignment between strategy and environment is needed (Ghemawat, 1991;

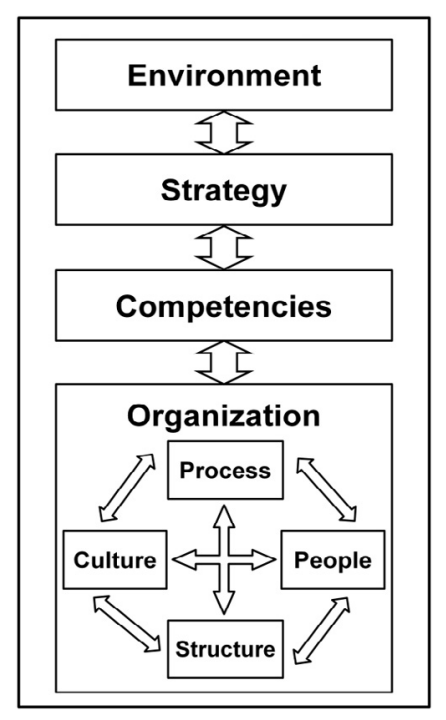

Figure 1. The ESCO model 
Peteraf, 1993), and managing change is the major strategic challenge faced by organizations (Brown and Eisenhardt, 1998). Strategic alignment is here seen as a continuous process, which requires the top management to balance both emergent and deliberate strategies (Mintzberg, 1987) with environmental demands and with strategy implementation.

The third domain of alignment in the ESCO framework is core competencies, which should be aligned with the strategy and the organization. The development of core competencies represents one of the key concepts within the resourcebased view (Barney, 1991; Prahalad and Hamel, 1990). It suggests that when a firm's resource and capability configurations are valuable, rare and imperfectly imitable, this is a source of competitive advantage (Barney et al., 2001). Whereas established routines and structures provide stability and increase efficiency, in many cases they prevent firms from renewing their current resource base. As a result, core competencies may turn into core rigidities (Leonard-Barton, 1992). More recently, the concept of dynamic capabilities has evolved, which relates to the proactive process of developing a resource base most adequately suited to the rapidly changing environment (Eisenhardt and Martin, 2000; Teece et al., 1997), and emphasizes the significance of capabilities such as flexibility, innovation, and self-organization (Miles et al., 1997; Rindova and Kotha, 2001).

Organization, the final element, deals with strategy implementation, and is constituted by the four components of structure, processes, people, and culture. Structure and processes have seen much attention in the academic literature, particularly in relation to strategy and performance (Bartlett and Ghoshal, 1991; Miles et al., 1978). A firm's structure entails aspects such as the division of tasks, centralization, coordination, and formalization that are all closely linked to organizational processes. These dimensions are seen as essential to the implementation of a chosen strategy; hence, as important determinants of corporate performance (Fredrickson, 1986). For instance, a highly formalized organizational structure facilitates precise decision-making, but at the same time reduces the level of flexibility and increases the likelihood of path-dependent behavior (Miller, 1986).

With regard to the people element, the key role of human resource management is to ensure organizational fit with the environment while allowing a healthy degree of flexibility (Christiansen and Higgs, 2008; Milliman et al., 1991; Wirtz et al., 2008). This can be achieved through coherence of human resource management with business strategy (Bennett et al., 1998; Schuler and Jackson, 1987). This involves a fit between a firm's strategy and human resource elements, such as recruitment, development and incentives, that support specific employee skills and behaviors (Wright and Snell, 1998). Christiansen and Higgs (2008), in line with Miles and Snow (1984b), found that firms with a tightly aligned human resource and business strategy achieve superior performance, compared to those that are misaligned.

With regard to the final element, culture, a distinction is made between internal and external cultural fit. The former is concerned with consistency of culture within the organization, while the latter addresses the degree of alignment between a corporate culture and a firm's strategy and environment (Arogyaswamy and Byles, 1987). Culture can be a major organizational strength if, for example, it provides a common identity for employees and a robust customer orientation. However, sources of misalignment derived from culture are also multifaceted. For example, misalignment between culture and strategy is likely to negatively influence implementation, and therefore the success of the strategy itself (Scholz, 1987). There is also a threat of a cultural clash and disruption of current norms when drastic changes in a firm's strategy or structure are made in response to environmental changes; this again can result in internal misalignment.

The driving force that bears responsibility and has the authority to take decisions and make resource allocation choices that can align the above levels is leadership (Powell, 1992). Such decisions can shape the firm's culture, strategic direction, core competency development, and strategy execution (Beal and Yasai-Ardekani, 2000; Gerard et al., 1999; Ramaswamy et al., 1994). Crossan et al. (2008), following Gardiner (2006), discuss "transcendent leadership", a holistic approach that highlights a leader's boundary-spanning task of acting within and across organizational levels to achieve alignment. Table 1 below illustrates the key concepts and authors relevant to strategic alignment.

Table 1

Key Concepts of Strategic Alignment

\begin{tabular}{|c|c|c|c|}
\hline & Categories & Relevant concepts & Key authors \\
\hline \multirow{3}{*}{$\begin{array}{l}\text { Key distinctions } \\
\text { in the literature }\end{array}$} & Conceptualizations of fit & Descriptive vs Normative fit & Venkatraman, 1989 \\
\hline & Outside-in alignment approach & Industrial organization, Contingency theory & Ginsberg \& Venkatraman, 1985; Porter, 1980 \\
\hline & Inside-out alignment approach & Resource-based view & Barney, 1991; Wernerfelt, 1984 \\
\hline \multirow{2}{*}{$\begin{array}{l}\text { Holistic strategic } \\
\text { alignment } \\
\text { frameworks }\end{array}$} & McKinsey 7-S & $\begin{array}{l}\text { Alignment among seven hard and soft } \\
\text { elements }\end{array}$ & Waterman, Peters \& Phillips, 1980 \\
\hline & ESCO & Alignment among four elements & Heracleous et al., 2009 \\
\hline \multirow[t]{4}{*}{$\begin{array}{l}\text { Levels of strategic } \\
\text { alignment }\end{array}$} & Environment & Dynamism, complexity, uncertainty & $\begin{array}{l}\text { Beer et al., 2005; Aragon-Correa \& Sharma, } \\
2003\end{array}$ \\
\hline & Strategy & Generic strategies, Dynamic models & $\begin{array}{l}\text { Ghemawat,1991; Miles et al., 1978; Peteraf, } \\
\text { 1993; Porter, } 1985\end{array}$ \\
\hline & Competencies & Resources, capabilities, dynamic capabilities & $\begin{array}{l}\text { Barney et al., 2001; Prahalad \& Hamel, 1990; } \\
\text { Teece et al., } 1997\end{array}$ \\
\hline & Organization & Structure, Process, People, Culture & $\begin{array}{l}\text { Miles et al., 1978; Fredrickson, 1986, Milliman } \\
\text { et al., 1991; Arogyaswamy \& Byles., } 1987\end{array}$ \\
\hline Driving force & Leadership & Leadership styles \& skills; Strategic impact & Crossan et al., 2008; Powell., 1992 \\
\hline
\end{tabular}


In comparison with the McKinsey 7-S model, the ESCO model adds the following. Firstly, it makes explicit reference to the external environment, thereby highlighting the importance of aligning strategy to this environment. Secondly, it makes explicit reference to sustainable competitive advantage as an outcome of alignment, thereby being consistent with a key goal of the strategic management field; linking strategy to performance outcomes, and underlining the importance of achieving alignment. Thirdly, it incorporates a higher level of elaboration and comprehensiveness than the 7-S model - each category is constituted by relevant subcategories, while at the same time retaining a balance with parsimony. Finally, the ESCO model is grounded in strategic management and organization literature, as described above.

\section{Understanding corporate failure}

Two broad views can be discerned in the literature on corporate failure: one deterministic, the other voluntaristic (Mellahi and Wilkinson, 2004). The deterministic view focuses on the external environment, and is mainly constituted by industrial organization (IO) and organizational ecology (OE) studies. From this perspective, corporate failure results largely from the impact of industry factors, rather than from the firm's internal factors (Barron, 2001).

The IO paradigm builds upon initial work conducted by the economist Schumpeter, who argued that drastic changes in the environment were responsible for extreme waves of industry entry and exit, and hence represented the major cause of failure (Schumpeter, 2003 (1943)). Subsequent work by Porter (1980) found that industry factors such as rivalry, entry barriers, and growth rate were key determinants of organizational performance or lack of it, and hence possible failure. Other related work has emphasized demand turbulence and competition as the major causes of decline and failure (Ghemawat, 1991; Lippman and Rumelt, 1983).

The second school within the deterministic view, organizational ecology, is grounded in the natural selection model developed by Hannan and Freeman (1977). With respect to corporate failure, four key elements have been outlined: population density, industry life cycle, age and size (Hamilton, 2006). In particular, the concept of population density has received much empirical attention (Dobrev et al., 2001; Hannan and Carroll, 1992). The "density-dependence" logic is based on the assumption that higher density leads to increased legitimacy, as well as increased competition (Hannan and Freeman, 1988), leading to a U-shaped relationship between density and failure (Agarwal et al., 2002). Further, the industry life cycle concept acknowledges the continuous transformations in an industry's structure and competitive environment that call for a timevariant approach when assessing the relationship between external factors and organizational survival (Agarwal et al., 2002). Failure in this perspective is considered to be a natural phenomenon dependent on varying market efficiencies (Klepper, 1996).

Much IO work has addressed the topic of organizational age and size, and failure (Baldwin and Gorecki, 1991; Lieberman, 1990). Stinchcombe's (1965) early study introduced the concept of liability of newness. Since then, numerous studies found an inverse relationship between age and failure, explained by a lack of experience, structure and stability of young firms (Carroll, 1983; Freeman et al., 1983). Liability of newness and its high risk of failure can also be applied to established firms that have undergone drastic changes, because these changes often disrupt established routines (Amburgey et al., 1993; Hamilton, 2006); even though change can also increase survival chances if there is higher alignment with the environment (Haveman, 1992; Stoeberl et al., 1998). Finally, with respect to organizational size, and following from the concept of the liability of smallness, it is generally agreed that failure rate decreases with increased firm size (Freeman et al., 1983; Sutton, 1987). The IO perspective has been useful in understanding industry dynamics as well as the impact of objective indicators such as age and size, but it does not address agents' behavioral motives or corporate internal factors, which have formed persistent critiques of this perspective over the years (Mellahi and Wilkinson, 2004).

In contrast to the deterministic school, the voluntaristic perspective constituted by organization studies (OS) and organizational psychology (OP) emphasizes internal factors including strategy, resources and capabilities, leadership, managerial cognition, managerial decision-making and organizational inertia, as fundamental to success or failure (Argenti, 1976; D’Aveni and MacMillan, 1990). For example, it has been argued that boards of directors that are passive, lack strategic thinking competencies, and are not involved in strategic decision-making, contribute to organizational decline and failure (D'Aveni and MacMillan, 1990; Finkelstein, 2006; Gilson, 1990; Mellahi, 2005). Further, narcissistic leaders who do not seek outside opinions and exhibit over-reliance on past behaviors and strategies are important determinants of organizational decline and failure (Maccoby, 2000; Rosenthal and Pittinsky, 2006).

A prominent concept of OS, initially arising from population ecology, is inertia (Hannan and Freeman, 1984). Inertia is present when the speed of environmental change is higher than the changes made in core features of an organization, as reflected in strategies, structures or behavioral capabilities (Hannan and Freeman, 1984). A highly formalized organizational structure established through high levels of standardized routines leads to increased corporate stability and reliability, but can also lead to structural and cognitive inertia and higher chances of failure if environmental dynamism and uncertainty increases (Kelly and Amburgey, 1991; van Witteloostuijn, 1998). Structural inertia increases with age and size, which make this phenomenon a more prominent concern for large, established firms (Stinchcombe, 1965).

Further, established institutional norms and constant conformity to certain long-established structural configurations may increase cognitive inertia, thus diminishing the appetite for change in the minds of top management (Barr and Huff, 1997). Hodgkinson and Wright (2002) describe cognitive inertia as a phenomenon that leads managers to become overly dependent upon established mental models to the detriment of change. Table 2 outlines the key concepts and authors relevant to corporate failure. 
Table 2

Perspectives on Corporate Failure

\begin{tabular}{|c|c|c|}
\hline & Concepts & Key authors \\
\hline \multirow{5}{*}{$\begin{array}{l}\text { Deterministic perspective - Industrial } \\
\text { organization and organizational } \\
\text { ecology }\end{array}$} & $\begin{array}{l}\text { Industry change / Environmental } \\
\text { uncertainty (IO) }\end{array}$ & $\begin{array}{l}\text { Anderson \& Tushman, 2001; Ghemawat, 1991; Lippman \& } \\
\text { Rumelt 1983, Porter } 1980\end{array}$ \\
\hline & Influence of other organizations (OE) & Baum \& Singh, 1994; Hannan \& Freeman, 1977 \\
\hline & Population density (OE) & $\begin{array}{l}\text { Hannan \& Carroll, 1992; Hannan \& Freeman, 1988; Zammuto } \\
\text { \& Cameron, } 1985\end{array}$ \\
\hline & Industry life cycle (OE) & Agarwal et al., 2002 \\
\hline & Age \& size (OE) & $\begin{array}{l}\text { Carroll, 1983; Freeman et al., 1983; Stinchcombe, 1965; } \\
\text { Sutton, } 1987\end{array}$ \\
\hline \multirow{3}{*}{$\begin{array}{l}\text { Voluntarist perspective - Organization } \\
\text { studies and organizational psychology }\end{array}$} & Top management strategic choices (OS) & Argenti, 1976; Child, 1972; Longenecker \& Simonetti, 1999 \\
\hline & Structural inertia (OS) & Hannan \& Freeman 1984, van Witteloostuijn 1998 \\
\hline & Cognitive inertia (OS/OP) & Barr \& Huff, 1997; Hodgkinson \& Wright, 2002 \\
\hline
\end{tabular}

Therefore, it can be seen that, in terms of the ESCO model, deterministic approaches to corporate failure mostly refer to the "environment" aspect of the model. Elements of the environment are depicted as changing, creating a context that leads to organizational success or failure for organizations, depending on their level of alignment with the new context. Organizations are assumed to be recipients of these changes without the ability to consciously do much to respond, at least in the short term. Voluntarist approaches, on the other hand, refer mostly to the strategy, competency and organization elements of the ESCO model, assuming these domains are under the prerogative of organizational actors, who can take strategic decisions and make choices in relation to them. Organizations here are seen as masters of their own fate.

\section{Methodology}

We pursued a qualitative research approach in the form of a dual case study design, within which we analyzed the two telecommunications firms WorldCom and Nortel Networks. This is a purposive sample, based on the following criteria. Firstly, the focal organizations experienced corporate-level failure, as indicated by bankruptcy filings. Secondly, the cases were in the same sector, to enable comparability and control for the influence of other factors such as the environment. The third criterion was that there was ample, rich published information on these focal organizations to enable us to track their trajectory that eventually led to failure. These documents included industry publications, scholarly journals, case studies, and press reports. They are listed in Appendix.

The case study design enabled us to examine the process over time through which these firms eventually reached failure, through an understanding of key aspects of the organizations including leadership, culture, and strategy, within their environmental context. The longitudinal/historical data gathered therefore allowed us to understand the "how and why" of outcomes (Yin, 2008).

As Mellahi and Wilkinson $(2004,34)$ argued, "any attempt to explain organizational failure will not be complete unless the interplay between contextual forces and organizational dynamics is taken into account". Taking on this challenge, we firstly gathered data on these two organizations from archival materials, being guided in our analysis by a focus on the ESCO elements including environmental trends, key strategic decisions, leadership characteristics, as well as prominent aspects at the organizational level such as corporate culture. In the process, we triangulated the data from various sources, which facilitated a deeper understanding of the organizational setting particularly with regard to internal issues. We stored the raw data in a case database that allowed repeated access throughout the research process as needed.

We employed this case database to produce a narrative for each organization, describing the process of decline and eventual failure over time. We then analyzed the narratives of each case with a focus on identifying the most prevalent types of misalignments present (as we outline in Tables 4 and 6, for example), and which misalignments were more influential in terms of enabling and leading to other types of misalignments. We also paid attention to temporal elements; i.e., the order in which misalignments appeared in each case.

We then moved from individual case analysis to cross-case analysis, to examine whether patterns could be identified across the two cases, a process that enhances external and internal validity of the analysis (Eisenhardt, 1989; Yin, 2008). The strategic alignment model applied to both cases - as well as the fact that the two organizations were facing similar environmental trends in the U.S. telecommunications industry - enhanced comparability. Based on this cross-case analysis, we identified the model of strategic misalignment and corporate failure presented in Figure 2, and populated the strategic alignment model presented in Figure 4.

\section{Analysis and findings}

\section{Strategic misalignments at WorldCom}

WorldCom was founded in 1983 under the name Long Distance Discount Service (LDDS). The company started as a small regional reseller of long distance phone services in Southern American states (Kaplan and Kiron, 2007). Two years after its 


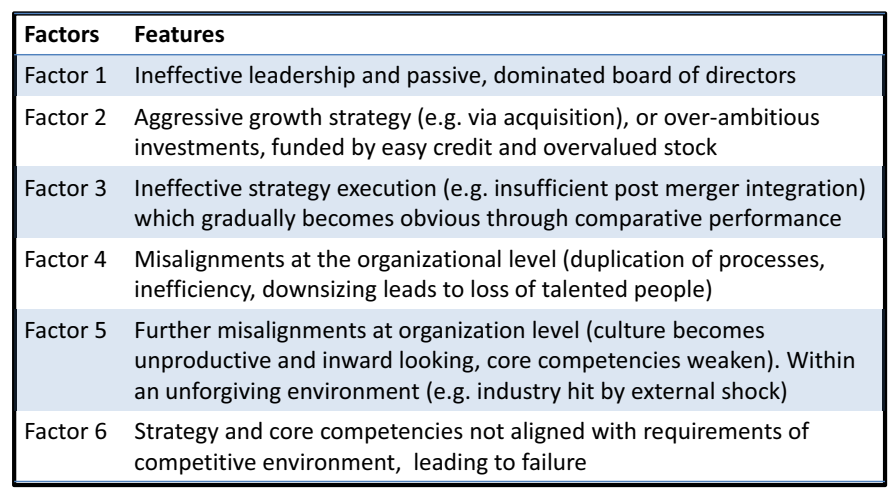

Figure 2. Factors Leading to Corporate Failure

founding, the company experienced early operational difficulties. At this time, the charismatic Bernie Ebbers, one of the firm's original investors, became chief executive officer (CEO). Ebbers would remain the only CEO in the company's history. Soon after becoming CEO, Ebbers initiated several takeovers of smaller resellers, implementing his vision of growth through acquisitions (Werhane et al., 2008). In 1989, the company went public. LDDS's corporate strategy at that point was one of related diversification and aggressive growth (Gollakota and Gupta, 2004). Through numerous acquisitions, the company gradually extended its network and eventually became a large player within the industry (Hamilton and Micklethwait, 2004). It expanded internationally by acquiring IDB Communications and changed its corporate name to WorldCom (WC) in 1995 (Hamilton and Micklethwait, 2004).

The 1996 Telecommunications Act allowed the company to enter the lucrative local telecom market, which was accomplished through several strategic partnerships (Werhane et al., 2008). WC also expanded its business scope into the mobile and Internet markets. The immense geographic coverage was competitively important for WC, as it significantly reduced complexity for its customers (Chan-Olmsted and Jamison, 2001).

Between 1985 and 2000, WorldCom acquired no less than 65 companies (Moberg and Romar, 2003), making larger and more complex acquisitions over time. Post-acquisition integration efforts relating to operations, services and business practices became increasingly multifaceted and time-consuming - an issue Ebbers and the senior team arguably did not address effectively (Jackson, 2009). Little effort was made to build a common mindset among different departments, which led to interunit rivalry and reluctance to cooperate (Moberg and Romar, 2003). Smaller integration problems (that later grew) were generally ignored, with managerial attention focused on the next deal (Hamilton and Micklethwait, 2004).

Various parts of the company operated with incompatible computer and billing systems, as well as non-cooperating customer service departments (Moberg and Romar, 2003), many of which had no record of customers registered with other parts of the company (Eichenwald, 2002). The wave of acquisitions, combined with problematic post-acquisition integration, complicated internal processes, created inefficiencies, and alienated customers (Hamilton and Micklethwait, 2004).

Through Ebbers' aggressive acquisition strategy, by 1997, the company had accumulated approximately $\$ 41$ billion in debt (Moberg and Romar, 2003). However, since access to funding remained easy, high debt obligations were a common occurrence among telecom companies. The continuing boom of the industry encouraged Ebbers to use WC's highly valued stock as currency for further aggressive growth. The firm's most significant acquisition took place in 1998, when WC bought $\mathrm{MCI}$, the nation's second-largest long distance provider, for \$37 billion - at the time the largest takeover in U.S. history (Gollakota and Gupta, 2009). The deal transformed WC into an international full-service phone company, named MCIWorldCom (MWC) (Kaplan and Kiron, 2007). The new conglomerate had an estimated market capitalization of $\$ 60$ billion (Stonham, 1998), and in June 1999 its stock price peaked at \$64.50 (Lorsch and Robertson, 2004).

The continuously expanding workforce, however, made up of employees from a multitude of acquired companies with their own history and culture, was not conducive to sustaining a sense of community within the organization, leading to rivalry and power struggles among employees (Hamilton and Micklethwait, 2004). WC's acquisition of MCI was an example of a lack of internal cultural coherence. MCI was a large, long-established company pursuing a differentiation strategy that had fostered a culture emphasizing product innovation, strong marketing and internal development (Gollakota and Gupta, 2004). Employees were given far more flexibility and decision-making authority than was common in WC, whose culture was established around lean operations, cost efficiencies and top-down decision-making (Hamilton and Micklethwait, 2004). There are no reports that WC's top management exerted any significant efforts to address these cultural issues. Seventyfive percent of former MCI high-level executives left shortly after the merger (Gollakota and Gupta, 2009).

WC's culture at the time has been described as autocratic, characterized by passive acquiescence and strict compliance by employees (Boudreau, 2008; Kaplan and Kiron, 2007), who were fearful of raising concerns, even if they noticed financial or other improprieties. WC's corporate culture was said to exhibit indications of groupthink, including near-blind loyalty and conformance, and insufficient examination of risks and alternative course of action (Scharff, 2005a). 
After 2000, the industry started witnessing a period of decline due to a slowdown in demand, as well as reduced yields resulting from fierce competition (Scharff, 2005b). During this time the company initiated accounting activities that would later be identified as fraudulent (Harmantzis, 2004). In 2000, MWC announced a \$115 billion merger with Sprint Communications, the third-largest U.S. telecom company, which owned a nationwide wireless network. However, the proposed deal was rejected by regulatory agencies (Gollakota and Gupta, 2009) and MWC never managed to establish its aspired strong position in the wireless segment (Hamilton and Micklethwait, 2004). This event appeared to be the turning point for the firm's historically glorious stock price, which lost its long upward momentum and then declined every subsequent year.

Despite its growth up to that point, MWC's profits and stock price experienced a drastic decline in 2001, which led to workforce reductions of 6,000 domestic jobs (Lorsch and Robertson, 2004). In the context of prominent bankruptcies such as Global Crossing and Enron, MWC's share price continued its downward slide and fell to under \$10 in 2002 (Hamilton and Micklethwait, 2004). Ebbers historically funded his private business activities with his personal company stock; however, when the value of his stock dropped, he started to use company loans and guarantees granted by the Board of Directors without any security. Ebbers' personal loans exceeded $\$ 400$ million by 2002 (Thornburgh, 2002).

Despite a drastic slowdown in the industry and a decline in MWC's profitability, Ebbers continued to report and project dynamic growth to the Board and to investors (Lorsch and Robertson, 2004). Rumors about the firm's alleged financial improprieties increased and, in March 2002, the Securities and Exchange Commission (SEC) started investigations into MWC's accounts (Gollakota and Gupta, 2009). One month later, Ebbers resigned as CEO (Werhane et al., 2008). At this time, a further 4,000 jobs were cut. In June 2002, auditors revealed a $\$ 4$ billion accounting fraud that they said had primarily been directed by Chief Financial Officer Scott Sullivan. He was fired shortly after (Hamilton and Micklethwait, 2004).

The SEC report later confirmed fraudulent practices in three areas, including accruals releases, capitalization of line costs, and revenue entries particularly during 2000-2002 (Kaplan and Kiron, 2007; Scharff, 2005b). The company's share price dropped to under $\$ 0.20$ by the end of June 2002, and MWC filed for Chapter 11 bankruptcy protection in July 2002. The firm's listed assets of $\$ 103.8$ billion made it the largest recorded bankruptcy in U.S. history (Werhane et al., 2008). Table 3 gives a chronology of key events at WorldCom.

Ebbers' leadership was characterized by a strict focus on growth through acquisition as well as tight cost control, which also underplayed the importance of human resource development (Hamilton and Micklethwait, 2004). Arguably, agency abuses occurred through Ebbers' personal business deals, which were guaranteed by company resources (Goolakota and Gupta, 2004; Scharff, 2005b). Even though the top management team was keen to pursue deals, they did not exercise sufficient control of finances, allowing the company to accumulate huge debts created by the wave of acquisitions, in addition to weak post-acquisition integration.

The board of directors was composed of four executive and nine non-executive directors, most of whom had been connected with acquired firms including as investors, former executives or directors (Gershon and Alhassan, 2004). Each of the directors owned more than a million WC shares (Beresford et al., 2003). Ebbers appeared to have total authority over the board, exercised through an autocratic leadership style similar to the one he applied to his subordinates (Gershon and Alhassan, 2004). Ebbers' power over the board was illustrated through the acquisition of Digex, which was conducted within a few days, and later described by a director as the "worst acquisition" and an "Ebbers ego-deal" (Hamilton and Micklethwait, 2004). Further, the directors authorized large loans to senior executives, and rubber-stamped additional bonuses and compensations as demanded by the CEO (Thornburgh, 2002), seemingly unaware of the accounting improprieties taking place within the organization (Beresford et al., 2003).

Case analysis indicates three main interconnected areas of misalignment. Firstly, between strategy and organization, due to aggressive expansion and insufficient integration of acquired firms. Secondly, internal misalignment due to problematic

Table 3

WorldCom - Chronology of events

\begin{tabular}{ll}
\hline $\mathbf{1 9 8 3}$ & Foundation of LDDC (Long Distance Discount Service) \\
$\mathbf{1 9 8 5}$ & Bernie Ebbers becomes CEO and remains in this position for the next 17 years \\
$\mathbf{1 9 8 9}$ & LDDC goes public \\
$\mathbf{1 9 9 4}$ & International expansion through acquisition of IDB Communications \\
$\mathbf{1 9 9 5}$ & LDDC becomes WorldCom (WC) and Sullivan takes on role as CFO \\
$\mathbf{1 9 8 5 - 1 9 9 7}$ & Continuous expansion through related diversification (numerous acquisitions which led to accumulated debt of \$41 billion in \\
$\mathbf{1 9 9 7}$ & Foll) \\
$\mathbf{1 9 9 8}$ & provider \\
$\mathbf{1 9 9 9}$ & Acquisition of MCI for \$37 billion (combined market capitalization of \$60 billion) \\
$\mathbf{2 0 0 0}$ & Stock price reaches historical peak of \$64.50 \\
$\mathbf{2 0 0 1}$ & Proposed merger with Sprint Communication is rejected by regulatory agencies \\
$\mathbf{2 0 0 2}$ (Spring) & Drastic decline of stock price and first wave of layoffs (6,000 employees) \\
$\mathbf{2 0 0 2}$ (Summer) & SEC commences investigations into Worldcom's accounting practices; further 4,000 jobs cut; Ebbers resigns \\
$\mathbf{2 0 0 3}$ (July) & Auditors reveal \$4 billion of accounting fraud; Scott Sullivan, CFO, is held mainly responsible for these practices and laid off; \\
& Share price drops below \$0.20 \\
& Worldcom files for bankruptcy, listing assets of \$103.8 billion \\
\hline
\end{tabular}


corporate culture and human resource practices. Thirdly, compounding the above, ineffective leadership and corporate governance. Table 4 summarizes these factors.

\section{Strategic misalignments at Nortel Networks}

Nortel Networks Corporation was founded in 1895, under the name Northern Electric and Manufacturing Company, after Canada's Telecom giant Bell Canada decided to spin off its manufacturing segment (Dhar and Manda, 2005). In its early years, the firm operated almost exclusively as a supplier of telephone equipment to its parent company Bell Canada (Wahl, 2004). Following a merger with Imperial Wire and Cable Company in 1914, the firm changed its name to Northern Electric Company. With substantial emphasis on research and development, Northern Electric developed highly successful digital switches in the 1970s, as well as advanced optical technologies in the 1990s (Vinluan, 2009a; Wahl, 2004).

In 1973, Northern Electric went public; Bell Canada regained almost full ownership in the company (Nortel Networks, 2014). Subsequent years were characterized by impressive growth, in which Northern Electric expanded both nationally and internationally (Vinluan, 2009b). In 1982, all Bell Operating Companies became independent entities (Nortel Networks, 2014). Within a short period of time after the liberalization, the company supplied products to nearly all Bell Operating Companies, and gradually evolved from a primarily Canadian supplier into a leading telecom company in America (Nortel Networks, 2014).

Newly appointed CEO Stern then refocused the firm's international strategy, and initiated important strategic partnerships in Europe in the late 1980s (Nortel Networks, 2014). The company increasingly undertook international acquisitions that aimed to appropriate technological capabilities in areas where the firm's own R\&D was weaker (Gassot et al., 2000). On its $100^{\text {th }}$ birthday in 1995, Northern Electric adopted a new corporate identity, Nortel Networks Corporation.

Nortel grew drastically in the late 1990s, aided by its strong stock value (Vinluan, 2009b), which reached a high of $\$ 124$ and a market capitalization exceeding $\$ 350$ billion (Tedesco, 2009). Revenues tripled within five years, reaching $\$ 30$ billion in 2000, when Nortel was serving customers in over 100 countries (Lefebvre et al., 2001). However, the industry witnessed major technological change, particularly with regard to the rapidly evolving Internet. Nortel's shift from a historical focus on telephone technology into the new era of Internet communications became inevitable.

In the late 1990s, Nortel developed a groundbreaking innovation in the optical connectivity segment that led to the firm's leading market position in subsequent years (Nortel Networks, 2014). In order to sustain its competitive edge in optical knowledge and consolidate its leading position, Nortel started acquiring specialist networking firms. The largest acquisition (BayNetworks) took place in 1998 for $\$ 9.1$ billion (Nortel Networks, 2014). The company's M\&A activity reached its zenith in 2000. In that year, eleven companies were purchased, for nearly $\$ 20$ billion (Dhar and Manda, 2005). In 2000, Bell Canada distributed most of its stake in Nortel to its shareholders (Nortel Networks, 2014). By June 2000, Nortel was the number one telecom supplier in the world in terms of revenues and reach (Frey, 2009; Lefebvre et al., 2001), based on its longstanding experience and expertise in designing and deploying networks, systems integration and new technologies (Rao et al., 2006).

Despite relatively high R\&D investments, Nortel's innovation processes slowed down, and groundbreaking innovations became very infrequent over the years. To compensate, and in the context of its aggressive growth strategy, Nortel made numerous acquisitions in order to gain new technological capabilities (Cherewayko, 2009). However, the integration of these firms and their technologies was not as effective is it could be; it complicated internal operations rather than improved innovative capabilities (Vinluan, 2009b).

Following the collapse of the telecom boom in 2000, Nortel implemented a radical downsizing program. During the years 2004-2006, CEO Owens drastically reduced Nortel's R\&D expenditures and closed several of its research centers (Datamonitor, 2008). This new strategic direction (emphasizing "buy" rather than "make", in terms of the "make or buy" decision) intensified the firm's outsourcing activities. Nortel not only subcontracted its manufacturing, but also product testing, repair and logistics, and later, even its HR department (Datamonitor, 2008). Further, the numerous waves of layoffs led to the loss of many of Nortel's talented employees. The constant fear of the next wave of layoffs led to a working environment with low morale, which was not conducive to creativity and innovation (Cherewayko, 2009; Rao et al., 2006).

The collapse of the industry boom after 2000 hit Nortel hard. The Internet network infrastructure had been overbuilt in terms of capacity, which led to a decline in levels of utilization, increased competition and price deflation. As a result, Nortel

Table 4

Main misalignments at WorldCom

\begin{tabular}{ll}
\hline Elements & Description \\
\hline Strategy and Organization & $\begin{array}{l}\text { Insufficient integration of acquisitions due to high complexity, volume, and speed, leading to: } \\
\text { Inter-unit rivalry, incompatible systems, redundancies, deficient financial integration, cultural clashes }\end{array}$ \\
Corporate culture and People & $\begin{array}{l}\text { Unhealthy work environment: lack of transparency, unclear responsibilities, low empowerment and people } \\
\text { development, high staff turnover, rivalry } \\
\text { Culture of passive acquiescence, unquestioned loyalty, autocracy, groupthink } \\
\text { Leadership and corporate } \\
\text { governance }\end{array}$ \\
& $\begin{array}{l}\text { Top management focuses on numbers and neglects human factors } \\
\text { of control over key decisions }\end{array}$ \\
\hline
\end{tabular}


had to cut costs further, and reduced its workforce by nearly 50\% (CBC, 2008). Many carriers filed for bankruptcy, caused by an overexpansion and significant accumulated debt during the industry's boom times (Dhar and Manda, 2005). Nortel lost numerous clients. Those still operating drastically reduced their budgets for telecom equipment purchases. This, in addition to broad price reductions amid fierce competition in the industry, caused Nortel's revenues to drop by almost $50 \%$ in 2001, and its stock price went into free fall.

The bursting of the industry bubble precipitated write-downs of $\$ 16$ billion in 2001, on the value of Nortel's prior acquisitions (Bagnall, 2009). The company had made several acquisitions that arguably did not align with the pursued strategy, or mismatched the technological trends of the environment (Wahl, 2004). Further, Nortel evaluated certain parts of the company as non-essential, such as the industrial design division, in sectors that later experienced growth and were seen by some as strategically important (Cherewayko, 2009). Nortel continued to produce equipment according to the "Code Division Access" wireless standard, which was technologically superior but not popular with telecom providers, most of whom used the European standard GSM (CBC, 2009).

A further critical event was the detection of fraudulent accounting practices in 2002, after which the firm was forced to restate several years of financial statements (Fogarty et al., 2009) and pay $\$ 500 \mathrm{~m}$ in accounting and legal fees (Corcoran, 2009). This absorbed much management time and energy, reducing focus on the external environment. Several key clients - Cingular Wireless, for example - defected to Nortel's competitors for the supply of the important third-generation network (Dhar and Manda, 2005). Problems continued with a downgrade of Nortel's long-term debt; its stock price falling below $\$ 1$, as well as the need for further restatements of its financial results (CBC, 2009).

A further investigation by the SEC took place in 2004, shortly after which Nortel's CEO and other executives were fired for financial mismanagement (Dhar and Manda, 2005). The new CEO Zafirovski announced a major restructuring program that involved structural realignments: Nortel reduced its key divisions to two; further jobs were cut; and additional outsourcing into low-cost regions was pursued (CBC, 2009; Reuters, 2008). However, these initiatives did not save Nortel from increased competition particularly from low-cost operators (Rao et al., 2006). Moreover, the firm had to bear the costs of fees and lawsuits following the accounting scandal, as well as bear the significant management distraction and reputational losses (CBC, 2009). Nortel had to re-restate its results several times, and became repeatedly unable to meet reporting deadlines (Dhar and Manda, 2005).

After 2005, the industry experienced increased consolidation involving both service providers and the equipment segment, where large mergers occurred between firms such as Cisco and Scientific-Atlanta (Datamonitor, 2008; Rao et al., 2006). It can be argued that during this time Nortel's management did not build strong partnerships, which could have strengthened its market position, particularly in the important wireless segment, and internationally against numerous low-cost providers.

In November 2008, Nortel announced a quarterly loss of $\$ 3.4$ billion. In January 2009, the board decided to apply for bankruptcy protection in both the U.S. and Canada (Gardner et al., 2009). Table 5 below summarizes the chronology of key events in Nortel's history.

During the period from 2001 to 2005, the firm's top management turnover was high, involving three different CEOs (GeorgeCosh, 2009). CEO Roth (1997-2001) initiated Nortel's repositioning in the late 1990s, but the company's debt obligations also increased exponentially in the course of an aggressive acquisition strategy. The firm's long-term debt was downgraded to junk status in 2002 (Robinson, 2005). CEO Dunn (2001-2004) was a key figure in the far-reaching accounting scandal,

Table 5

Nortel - Chronology of events

\begin{tabular}{|c|c|}
\hline 1895 & Founding of Northern Electric and Manufacturing Company, spinoff from Bell Canada \\
\hline 1914 & Renamed to Northern Electric Company following merger with Imperial Wire and Cable Company \\
\hline 1973 & Northern Electric goes public; Bell Canada majority owner; core business is provision of telecom equipment \\
\hline 1980s & Exponential growth nationally and internationally; several acquisitions aimed to acquire needed technology \\
\hline 1995 & $100^{\text {th }}$ birthday: Renamed to Nortel Networks and positioned as global integrated network solution provider \\
\hline 1997 & $\begin{array}{l}\text { CEO Roth initiates wave of acquisitions ( } 17 \text { in total; } 11 \text { just in } 2000 \text { worth } \$ 20 \mathrm{bn} \text { ) aiming to strengthen Nortell's focus and } \\
\text { capabilities on high-speed networks, from telephone switches }\end{array}$ \\
\hline 2000 & $\begin{array}{l}\text { Peak of Telecom Boom; Nortel top telecom supplier, with over 95,000 employees; revenues triple in } 5 \text { years to } \$ 30 \mathrm{bn} \text {; stock } \\
\text { price rises to } \$ 124 \text { and market capitalization reaches } \$ 350 \text { bn. But. . Bell Canada drastically reduces its stake and CEO Roth } \\
\text { cashes in stock options worth C } \$ 135 \mathrm{~m}\end{array}$ \\
\hline 1995-2000 & $\begin{array}{l}\text { Meanwhile, debt built up; passive board of directors did not question reckless expansion; weak audit and accounting control } \\
\text { system; high levels of organisational complexity from weak post-merger integration }\end{array}$ \\
\hline 2001 & $\begin{array}{l}\text { Collapse of Internet/Telecom boom: many clients go bankrupt or slash purchasing budget; price deflation; Nortel's revenues } \\
\text { decline by } 50 \% ; 45,000 \text { jobs cut; stock price in freefall; acquisition write-downs of } \$ 16 \text { bn }\end{array}$ \\
\hline 2002 & Detection of accounting fraud; share price drops further; drastic restructuring, 10,000 further job losses \\
\hline 2004 & Restatement of 2003 profits after further financial irregularities detected; top team fired for financial mismanagement \\
\hline 2005 & $\begin{array}{l}\text { New CEO Zafirovski initiates another radical restructuring program; downscoping by selling divisions; further reductions in } \\
\text { headcount, additional outsourcing }\end{array}$ \\
\hline 2006-2008 & $\begin{array}{l}\text { Depressed revenues and fierce competition; layoffs reduce morale, many talented employees leave, creativity and innovation } \\
\text { declines; stock price drops below } \$ 1 \text { in } 2008 \text {, company de-listed }\end{array}$ \\
\hline 2009 & Nortel files for bankruptcy in January \\
\hline
\end{tabular}


and initiated the downsizing program, which reduced cost but also led to quality and innovation problems. CEO Zafirovski (2004-2005) initiated further restructuring, but was not able to achieve a successful turnaround of the company.

Nortel's board of directors arguably did not exercise their monitoring function effectively, having lost control over top management, particularly with respect to the aggressive expansion and creation of the risky debt burden during Roth's tenure. The board consisted of twelve members who arguably did not have deep industry expertise, and who retained multiple commitments that reduced the time and attention they could devote to Nortel (Anderson, 2009; Taylor, 2004). The board continued to grant generous bonuses to executives, even during the period of Nortel's decline. Most significantly, however, directors did not ensure the institution of robust strategic and financial control mechanisms, which allowed aggressive acquisitions and fraudulent accounting practices to occur (Datamonitor, 2008). Nortel's corporate governance lacked an effective audit system, and the board's own performance was never assessed through an evaluation process that might have led to a board restructuring (Thain, 2004). The above also call into question the board's independence from senior management.

Three main areas of misalignment can be identified as being most significant, and ultimately leading to the downfall of Nortel: a misalignment between strategy and environment; a misalignment between strategy and competencies; and, a misalignment affecting all levels of the organization, rooted in ineffective leadership and corporate governance. External industry factors contributed to Nortel's ultimate failure, by exacerbating the effects of these misalignments. Table 6 below outlines these misalignments.

\section{Cross-case analysis: patterns of corporate failure}

Cross-case analysis revealed both similarities and differences between the two cases. With respect to differences, the age of the two organizations was markedly different; WorldCom was set up in 1983 and declared bankruptcy in 2002, whereas Nortel was founded in 1895 and declared bankruptcy in 2009. The time spans of decline as well as turnaround efforts were also markedly different. WorldCom's decline was swift, from the first signs in 1999 to 2002, during which CEO Ebbers initiated relatively incremental changes to the strategy. Decline at Nortel occurred over nine years, from 2000 to 2009, and radical turnaround actions such as restructuring and cost cutting were initiated. Finally, there were marked differences in the dominance of the CEO; since 1985, WorldCom had just one CEO, Ebbers, whereas Nortel had high levels of top management turnover, particularly during the period from 2001 to 2005.

Despite the marked differences, there were some significant commonalities. Both firms operated in the U.S. telecoms industry, facing similar external forces, including level of competition, technological developments and government regulations. The telecom boom in the 1990s led to overvalued stock prices and easy access to credit, enabling both to pursue aggressive acquisition and growth strategies. Both were hit hard when the telecom bubble burst, leading to difficulties in servicing their high levels of debt after 2000. Both exhibited fraudulent accounting practices and faced SEC investigations.

In both cases, the leadership and corporate governance systems played a crucial role in the process that began their progression towards demise. In both organizations, ineffective leadership combined with a passive board of directors that did not provide the required control, guidance and stewardship of the company. Further, both WorldCom and Nortel pursued a very similar, aggressive growth strategy through acquisition. Both firms witnessed negative consequences of this strategy at the organizational level, where the extent and speed of acquisition activity led not only to ineffective post-merger integration and high levels of debt, but subsequently to various types of organizational problems, such as increased complexity and attendant inefficiencies, low morale and power plays. These were most obvious at the level of people and processes, over time negatively affecting the culture and core competencies of the organizations, and finally accentuating the misalignment between the strategy and the imperatives posed by the competitive environment, leading to failure. Figure 2 below displays this process.

Table 6

Main misalignments at Nortel

\begin{tabular}{|c|c|}
\hline Elements & Description \\
\hline \multirow{2}{*}{$\begin{array}{l}\text { Strategy and core } \\
\text { competencies }\end{array}$} & Aggressive acquisitions did not address problems of slow and infrequent innovations in late 1990s \\
\hline & $\begin{array}{l}\text { Radical downsizing in 2000; layoffs and reduced R\&D expenditure, loss of former competitive advantage in terms of } \\
\text { technology and innovations }\end{array}$ \\
\hline \multirow[t]{4}{*}{$\begin{array}{l}\text { Strategy and external } \\
\text { environment }\end{array}$} & $\begin{array}{l}\text { Aggressive acquisition strategy during telecom boom in late 1990s, involving overpriced acquisitions, leads to high } \\
\text { levels of debt and risk }\end{array}$ \\
\hline & Telecom market crash in 2000 leads to reduced growth and profitability rates \\
\hline & Inward orientation of management following accounting scandal \\
\hline & Missed opportunities to build strategic partnerships and failure to keep up with dynamic environment \\
\hline \multirow{5}{*}{$\begin{array}{l}\text { Leadership and corporate } \\
\text { governance }\end{array}$} & High levels of top management turnover \\
\hline & Aggressive, uncontrolled expansion led by CEO Roth leads to large debt obligations \\
\hline & Downsizing, numerous layoffs, financial mismanagement (led by CEO Dunn) \\
\hline & Drastic restructuring led by CEO Zafirovski unsuccessful in revitalizing Nortel \\
\hline & Board of directors ineffective as a control mechanism, allowing risky expansion and not detecting accounting fraud \\
\hline
\end{tabular}


We should clarify here that, even though Figure 2 presents the process in terms of certain factors, it is possible that the road to failure does not involve all of these factors, or that it incorporates other building blocks that we do not identify here. There are also feedback loops and dynamic interactions among these factors - for example, misalignments at the organizational level (factor 4) creating a vicious circle by amplifying ineffective strategy execution (factor 3 ), and fostering even greater misalignments at the organizational level (factor 5). Despite the linear depiction of Figure 2, we do not present this model as a necessarily linear progression, but rather as a series of interrelated factors that can explain why these two oncesuccessful organizations became bankrupt. Subsequent research can explore whether this model applies to other bankruptcy situations in other industry contexts.

\section{Discussion}

Our aim in this study was to advance understanding of the phenomenon of corporate failure by adopting a longitudinal perspective. Our analysis led to a six-factor process-oriented model, culminating in corporate failure. From a deterministic perspective on corporate failure, the impact of environmental change and industry conditions on organizations' performance is significant. In the two cases we analyzed, the industry downturn was a precipitating factor for failure. Our study additionally illustrates how, from a voluntaristic perspective, internal organizational factors such as the quality of leadership and corporate governance, as well as the soundness of strategic decisions and the effectiveness of their execution, are prime contributors to success or failure. These findings are consistent with strategic management research on the relative effects of industry factors versus organizational factors on corporate performance (McGahan and Porter, 1997; Rumelt, 1991), as well as with the strategic choice perspective (Child, 1972,1997), which highlights the role of managerial agency. Specific environmental trends have differential impact on organizations, depending on organizations' internal factors such as organization design and competencies, as well as strategic choices. Consistent with the relevant literature (Crossan et al., 2008; Powell, 1992), we found that leadership and corporate governance are crucial antecedent factors to corporate failure, which act as driving factors of strategic alignment as well as misalignments, as seen in the two case studies we analyzed.

Employing this insight of the fundamental role of leadership as corroborated by our findings, as well as the relationship between alignment and performance, we develop Figure 3 below. The framework builds upon Heracleous et al.'s (2009) ESCO framework, and extends this by including leadership and the board of directors as driving forces for strategic and organizational decisions, as well as success or failure as an explicit outcome. Further, the various domains of alignment are elaborated in the model, based on relevant factors identified in the literature and noted in our earlier discussion. This framework offers an integrative perspective of the various factors relevant to both organizational performance, as well as failure.

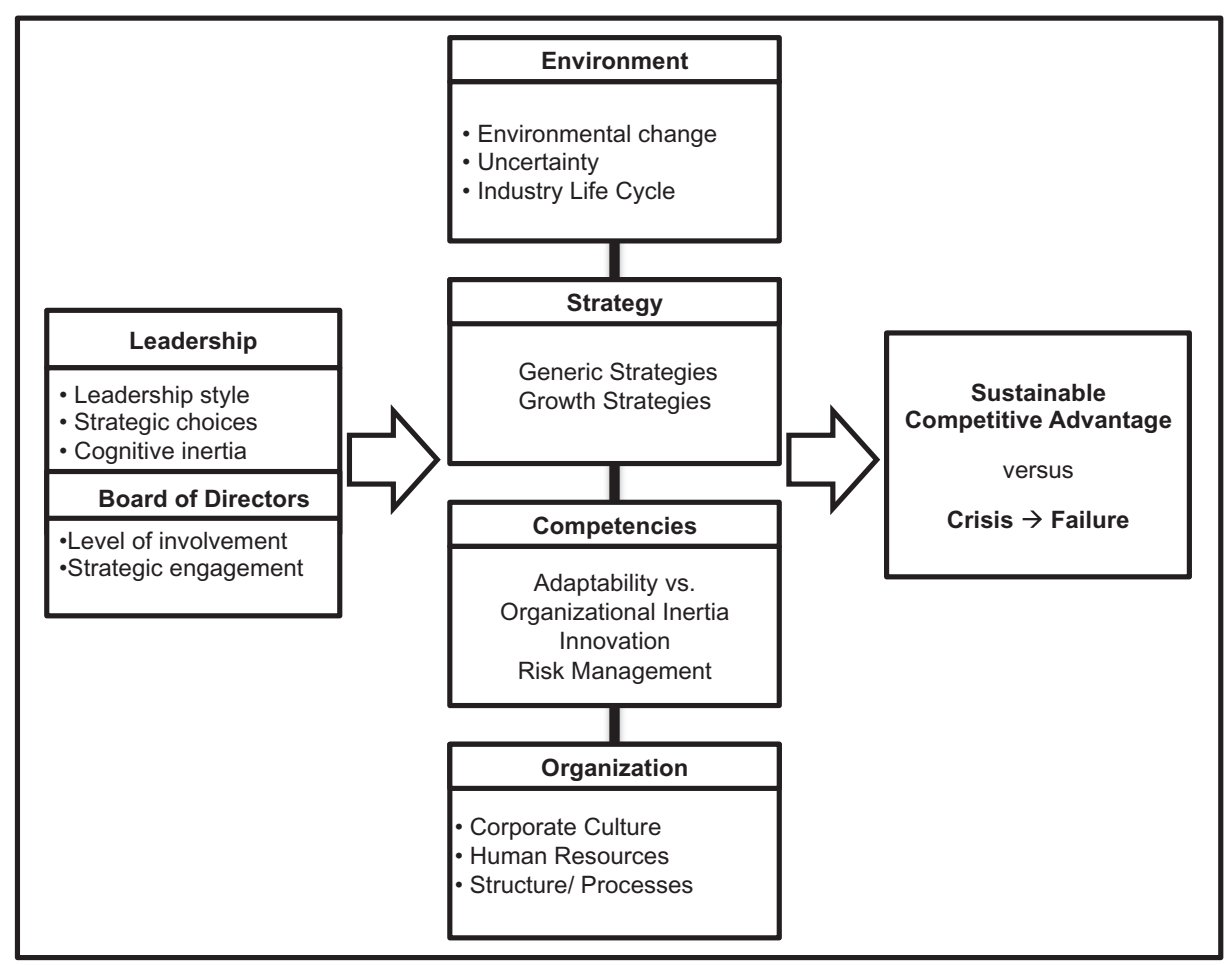

Figure 3. Strategic Alignment Model 
The factors leading to failure presented in Figure 2 and the ESCO model are closely interrelated. The starting point of the extended ESCO model - Leadership and Board of Directors - is also the starting point of the process towards success or failure. Leadership is responsible for taking the tough decisions pertaining to alignment, and can lead the organization to sustainable advantage. However, if leadership is dysfunctional the organization can go down a path that will lead to ultimate failure. Other elements of our model map closely with the elements of the ESCO model. Factor 2 pertains to the Strategy element of the ESCO model, and factors 3 to 5 relate to the Organization and Competency elements of the ESCO model. Factor 6 relates to a fatal level of misalignments between the external, Environment element and the internal elements of the ESCO model. Finally, both the factors in Figure 2 and the ESCO model relate to certain outcomes. In the former case, they relate to failure due to misalignments; in the latter case to either failure or success depending on the level of alignment. Figure 4 below incorporates the misalignment patterns into the ESCO model, highlighting the interconnected and dynamic nature of these patterns.

Further, the model of corporate failure in Figure 2 shows that failure should not be understood simply as the result of a single wrong action such as accounting fraud, or a single strategic decision such as an ill-fated acquisition. Rather, it extends understanding of corporate failure, by highlighting that it is a process arrived at over time, through interrelated antecedents. The three initial factors - ineffective leadership and governance, followed by unduly risky strategic decisions and then by lax implementation - set the stage for failure, since they precipitate various types of organizational misalignments that enlarge the gap between the strategy and competencies of the organization on the one hand, and the demands of the external environment on the other hand.

In terms of implications for practice, the frameworks developed in this study (the model of failure in Figure 2, and the strategic alignment framework in Figure 3) can be employed as important diagnostic tools by senior managers, strategic planners, or consultants to evaluate potential misalignments and, if appropriate, to gain advance warning of whether the organization is on the way to failure. Importantly, such an analysis would then allow a firm to take appropriate actions to arrest the process, which would be crucial in order to achieve a successful turnaround. The model of failure in Figure 2 can offer an early warning system of the development of strategic misalignments, raising awareness of important antecedents of strategic misalignments, potentially allowing a firm to take action at an early stage.

Further, the findings point to a back-to-basics approach for senior executives. They remind us of the crucial role of leadership and governance (factor 1), the limits and dangers of risky and aggressive growth strategies (factor 2), and the vital importance of effective execution (factor 3). A dominant CEO combined with a passive board can enable aggressive growth strategies to go unchecked. Such strategies can become a stone around the neck of organizations if the environment turns sour, and if in the meantime they have built up substantial debt they cannot service once their performance and share prices decline. A risky strategy badly executed is a recipe for failure. It leads to organizational misalignments that gradually spread,

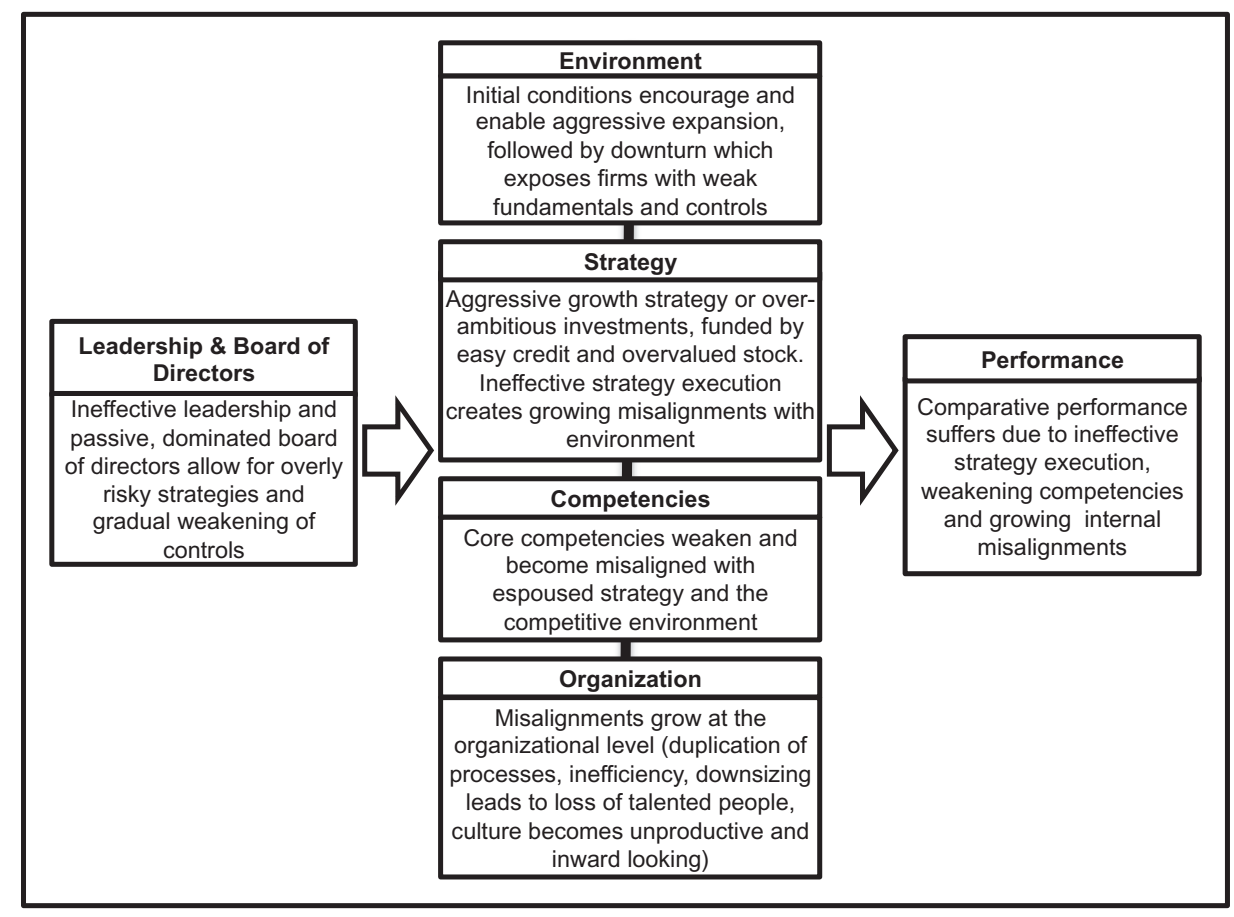

Figure 4. Misalignment Patterns Positioned in the Strategic Alignment Model 
to put the organization in a highly compromising position, from which it is almost impossible to recover. Being aware of these risk factors and avoiding them, is essential for leaders and boards of directors.

\section{Appendix. Documents Informing Analysis of WorldCom, Nortel and the Telecommunications Industry}

Anderson, M., 2009. Nortel Leadership Seems to Have Gone by the Board. [online] <http://0-global.factiva.com.pugwash .lib.warwick.ac.uk/aa/?ref=OTCT000020090128e51s00036\&pp=1\&fcpil=en\&napc=S\&sa_from=> (accessed 15.07.10.).

Atkin, D.J., Lau, T.-Y., Lin, C.A., 2006. Still on hold? A retrospective analysis of competitive implications of the telecommunication act of 1996, on its 10th year anniversary. Telecommunications Policy 30 (2), 80-95.

Aufderheide, P., 2006. The 1996 telecommunications act: Ten years later. Federal Communications Law Journal 58 (3), 407-413.

Bagnall, J., 2009. The Beginning of the End. [online] <http://www.ottawacitizen.com/story_print.html?id=2165259\&sponsor=> (accessed 07.07.10.).

Beresford, D., Katzenbach, N., Rogers, C.B., 2003. Report of Investigation. [online] <http://news.findlaw.com/wsj/ docs/WorldCom/bdspcomm60903rpt.pdf> (accessed 09.07.10.).

Boudreau, A., 2008. WorldCom Scandal: Impact of Organizational Behavior on Company Failure. [online] <http://alexboudreau .files.wordpress.com/2009/11/WorldCom-scandal-ethicalimplications-boudreau-2008.pdf> (accessed 05.07.10.).

CBC (Canadian Broadcasting Corporation), 2008. The Wild Ride of Canada's Most-watched Stock. [online] <http://www.cbc.ca/news/background/nortel/stock.html> (accessed 08.07.10.).

CBC (Canadian Broadcasting Corporation), 2009. Canada's Technology Star becomes Financial Black Hole. [online] $<$ http://www.cbc.ca/money/story/2009/01/14/f-nortel-backgrounder-january09.html> (accessed 07.07.10.).

Chan-Olmsted, S., Jamison, M., 2001. Rivalry through alliances: Competitive strategy in the global telecommunications market. European Management Journal 19 (3), 317-333.

Cheng, J.Z., Tsyu, J.Z., Yu, H.D., 2003. Boom and gloom in the global telecommunications industry. Technology in Society 25 (1), 65-81.

Cherewayko, C., 2009. Charting the Rise and Fall of Nortel Networks. [online] <http://www.techvibes.com/blog/ charting-the-rise-and-fall-of-nortel-networks> (accessed 08.07.10.).

Corcoran, T., 2009. Nortel's Rise and Fall as 'Chosen Instrument'. [online] <http://0-global.factiva.com .pugwash.lib.warwick.ac.uk/aa/?ref=FINP000020090115e51f0001k\&pp=1\&fcpil=en\&napc=S\&sa_from=> (accessed 07.07.10.).

Datamonitor, 2008. Company spotlight: Nortel networks corporation. MarketWatch: Global Round-up 7 (6), 241-248.

Dhar, S., Manda, S., 2005. Nortel networks: The canadian telecommunications equipment Giant's accounting controversies. ECCH Case Study 305-133-1: 1-6.

Doherty, J., 2001. Telecom tightrope. Barron's New York 81 (2), 17-18.

Eichenwald, K., 2002. For WorldCom, Acquisitions Were Behind Its Rise and Fall. [online] <http://www .latrobefinancialmanagement.com/Research/Accounting/For\%2520WorldCom\%2520Acquisitions\%2520were \%2520behind\%2520its\%2520rise\%2520and\%2520fall.pdf> (accessed 12.07.10.).

Fogarty, T., Magnan, M.L., Markarian, G., 2009. Inside agency: The rise and fall of Nortel. Journal of Business Ethics 84 (2), 165-187.

Forbes Digital, 2010. The Industry Handbook: The Telecommunications Industry. [online] <http://www.investopedia.com/ features/industryhandbook/telecom.asp> (accessed 30.06.10.).

Foreman, R.D., 2003. A logistic analysis of bankruptcy within the US local telecommunications industry. Journal of Economics and Business 55 (2), 135-166.

Fransman, M., 2002. Evolution of the Telecommunications Industry into the Internet Age. [online] <http://www .telecomvisions.com/articles/pdf/FransmanTelecomsHistory.pdf> (accessed 15.06.10.).

Fraquelli, G., Vannoni, D., 2000. Multidimensional performance in telecommunications, regulation and competition: Analysing the european major players. Information Economics \& Policy 12 (1), 27-46.

Frey, W., 2009. Nortel's Rise and Fall, as seen by their CTO. [online] <http://www.techvibes.com/blog/ nortels-rise-and-fall-as-seen-by-their-cto> (accessed 07.07.10.).

Gardner, R., Yeoh, F., Howe, M., 2009. Counterparty Exposure: The Fall of Nortel. [online] <http://www.redington.co.uk/ assets/pdf/redviews/Counterparty\%20Exposure-\%20The\%20Fall\%20of\%20Nortel.pdf> (accessed 07.07.10.).

George-Cosh, D., 2009. Nortel CEOs in the Good Times and Bad. [online] <http://0-global.factiva.com.pugwash .lib.warwick.ac.uk/aa/?ref=FINP000020090115e51f0000y\&pp=1\&fcpil=en\&napc=S\&sa_from $=>$ (accessed 09.07.10.).

Gershon, R.A., Alhassan, A.D., 2004. AOL Time Warner \& WorldCom Inc.: Corporate Governance and Diffusion of Authority. [online] <http://www.cem.ulaval.ca/pdf/gershon_alhassan.pdf> (accessed 05.07.10.).

Gollakota, K., Gupta, V., 2004. WorldCom Inc.: Survival at Stake. Journal of the International Academy for Case Studies 10 (4), 67-76.

Gollakota, K., Gupta, V., 2009. WorldCom Inc.: What went wrong. Ivey School of Business Case Study 905M43: 1-12.

Hamilton, S., Micklethwait, A., 2004. WorldCom: The Downfall of a Giant. ECCH Case Study IMD-1-0214: 1-24.

Harmantzis, F.C., 2004. Inside the Telecom Crash: Bankruptcies, Fallacies and Scandals - A Closer Look at the WorldCom Case. Working paper, Stevens Institute of Technology: Wesley J. Howe School of Technology Management.

Jackson, P., 2009. WorldCom: An Ethical Case Study. [online] <http://www.sampledisplay11.com/PJacksonPortfolio/ Adm\%20Policy-\%20WorldCom.pdf> (accessed 14.07.10.). 
Kaplan, R.S., Kiron, D., 2007. Accounting fraud at WorldCom. Harvard Business School Case Study 9-104-071: 1-18.

Kerner, S.M., 2009. Nortel Bankruptcy a Canadian Tragedy. [online] <http://www.internetnews.com/commentary/article.php/ 3796971/Nortel-Bankruptcy-a-Canadian-Tragedy.htm> (accessed 15.07.10.).

Kimmelman, G., Cooper, M., Herrera, M., 2006. The failure of competition under the 1996 telecommunications act. Federal Communications Law Journal 58 (3), 511-518.

Lefebvre, L.-A., Leger, P.-M., Cassivi, L., Lapointe, R., Hadaya, P. 2001. OECD Electronic commerce business impacts project: The case of the Canadian optical connectivity equipment value chain. [online] <http://www.oecd.org/sti/ieconomy/ 2070352.pdf> (accessed 12.12.2014.).

Lorsch, J.W., Robertson, A.C., 2004. Restoring trust at WorldCom. Harvard Businnes School Case Study 9-404-138: 1-26.

Moberg, D., Romar, E., 2003. Case Study: WorldCom. [online] <http://www.scu.edu/ethics/dialogue/candc/cases/ WorldCom.html> (accessed 10.07.10.).

Nortel Networks, 2014. History of Nortal. [online] <http://www.nortelcanada.com/about/history/> (accessed 15.12.14.).

Rao, B., Kumar, K., Bhaskaran, S., 2006. The future for Nortel: 2006 and beyond. ECCH Case Study 306-553-1: 1-15.

Reuters, 2008. Timeline: Key Dates in Nortel's Corporate History. [online] <http://www.reuters.com/article/ idUSN1717250220080917> (accessed 08.07.10.).

Robinson, L.A., 2005. Nortel Networks Corporation: Ethical Missteps. [online] <http://accounting.uwaterloo.ca/ethics/ Management_Fraud/Nortel\%20Case.doc> (accessed 10.07.10.).

Rosensbush, S., 2005. Five Lessons of the WorldCom Debacle. [online] <http://www.businessweek.com/print/technology/ content/mar2005/tc20050316_9160_tc024.htm?chan=tc> (accessed 01.07.10.).

Scharff, M., 2005a. Understanding Worldcom's accounting fraud: Did groupthink play a role? Journal of Leadership \& Organizational Studies 11 (3), 109-118.

Scharff, M., 2005b. WorldCom: A failure of moral and ethical values. Journal of Applied Management and Entrepreneurship 10 (3), 35-47.

Stonham, P., 1998. Takeover frenzy in telecoms: The case of MCI WorldCom (Part one: competitive strategies). European Management Journal 16 (3), 318-326.

Taylor, P., 2004. Nortel Networks Chief to Quit Board Roles. [online] <http://ft.chadwyck.co.uk/ft/ printItem.do?ItemID=20040501U209.015> (accessed 10.07.10.).

Tedesco, T., 2009. Nortel: The Sad Fall of Canada's Corporate Giant. [online] <http://www.financialpost.com/ story.html?id=1177541> (accessed 07.07.10.).

Thain, D.H., 2004. Reflections of a veteran director: The unsatisfactory Performance of Nortel's 'distinguished' board. Ivey Business Journal, May/June 1-4.

Thornburgh, D., 2002. Woldcom Inc.: First Interim Report of Dick Thornborough, Bankruptcy Court Examiner. [online] $<$ http://news.findlaw.com/hdocs/docs/WorldCom/bkexmnr60903rpt2d.pdf> (accessed 12.07.10.).

Vinluan, F., 2009a. The Rise and Fall of Nortel: Timeline. [online] <http://triangle.bizjournals.com/triangle/stories/ 2009/08/24/story5.html> (accessed 07.07.10.).

Vinluan, F., 2009b. The Rise and Fall of Nortel: Unwise Acquisitions, Scandal Led to Downfall. [online] $<$ http://triangle.bizjournals.com/triangle/stories/2009/08/24/story3.html> (accessed 07.07.10.).

Wahl, A., 2004. Nortel's next big thing. Canadian Business 77 (3), 49-56.

Wang, G., 2003. Foreign investment policies, sovereignty and growth. Telecommunications Policy 27 (3/4), 267.

Werhane, P., Wicks, A., Sack, R., Mead, J., 2008. WorldCom: Keeping planes in the air. ECCH Case Study UVA-E-0335: 1-15.

Zekany, K., Braun, L., Warder, Z., 2001. Behind closed doors at WorldCom: 2001. Issues in Accounting Education 19 (1), 101-117.

\section{References}

Agarwal, R., Sarkar, M.B., Echambadi, R., 2002. The conditioning effect of time on firm survival: a life cycle approach. Academy of Management Journal 45 (5), 971-994.

Amburgey, T., Kelly, D., Barnett, W.P., 1993. Resetting the clock: the dynamics of organizational change and failure. Administrative Science Quarterly 38 (1), 51-73.

Anderson, P., Tushman, M.L., 2001. Organizational environments and industry exit: the effects of uncertainty, munificence and complexity. Industrial and Corporate Change $10(3), 675-711$.

Aragon-Correa, J.A., Sharma, S., 2003. A Contingent Resource-Based View of Proactive Corporate Environmental Strategy. Academy of Management Review $28(1), 71-88$

Argenti, J., 1976. Corporate planning and corporate collapse. Long Range Planning 9 (6), 12-17.

Arogyaswamy, B., Byles, C.M., 1987. Organizational culture: internal and external fits. Journal of Management 13 (4), 647.

Baldwin, J.R., Gorecki, P.K., 1991. Firm entry and exit in the Canadian Manufacturing Sector, 1970-1982. Canadian Journal of Economics 24 (2), 300-323.

Barney, J., 1991. Firm resources and sustained competitive advantage. Journal of Management 17 (1), 99-120.

Barney, J., Wright, M., Ketchen, D.J., Jr., 2001. The resource-based view of the firm: ten years after 1991. Journal of Management 27 (6), 625-641.

Barr, P.S., Huff, A.S., 1997. Seeing isn't believing: understanding diversity in the timing of strategic response. Journal of Management Studies 34 (3), 337-370. Barron, N.B., 2001. Organizational ecology and industrial economics: a comment on Groski. Industrial and Corporate Change 10, 541-548.

Bartlett, C.A., Ghoshal, S., 1991. Global strategic management: impact on the new frontiers of strategy research. Strategic Management Journal 12 (S1), 5-16.

Baum, J., Singh, J., 1994. Organizational Niches and the Dynamics of Organizational Mortality. Administrative Science Quarterly 100 (2), $346-380$.

Beal, R.M., Yasai-Ardekani, M., 2000. Performance implications of aligning CEO functional experiences with competitive strategies. Journal of Management $26(4), 733-762$

Beer, M., Voelpel, S.C., Leibold, M., Tekie, E.B., 2005. Strategic management as organizational learning: developing fit and alignment through a disciplined process. Long Range Planning 38 (5), 445-465. 
Bennett, N., Ketchen, D.J., Jr., Schultz, E.B., 1998. An examination of factors associated with the integration of human resource management and strategic decision making. Human Resource Management 37 (1), 3-17.

Brown, S.L., Eisenhardt, K. 1998. Competing on the Edge: Strategy as Structured Chaos. Harvard Business School Press, Boston, MA.

Carroll, G.R., 1983. A stochastic model of organizational mortality: review and re-analysis. Social Science Research 12 (4), 303-329.

Chabrak, N., Daidj, N., 2007. Enron: widespread myopia. Critical Perspectives on Accounting 18 (5), 539-557.

Child, J., 1972. Organizational structure, environment and performance: the role of strategic choice. Sociology 6 (1), 1-22.

Child, J., 1997. Strategic choice in the analysis of action, structure, organizations and environment: retrospect and prospect. Organization Studies 18 (1), 43-76.

Christiansen, L.C., Higgs, M., 2008. How the alignment of business strategy and HR strategy can impact performance. Journal of General Management 33, 13-33.

Crossan, M., Vera, D., Nanjad, L., 2008. Transcendent leadership: strategic leadership in dynamic environments. Leadership Quarterly 19 (5), 569-581.

D'Aveni, R.A., MacMillan, I.C., 1990. Crisis and the content of managerial communications: a study of the focus of attention of top managers in surviving and failing firms. Administrative Science Quarterly 35 (4), 634-657.

Dobrev, S.D., Kim, T.-Y., Hannan, M.T., 2001. Dynamics of niche width and resource partitioning. American Journal of Sociology 106 (5), $1299-1337$.

Eisenhardt, K.M., 1989. Building theories from case study research. Academy of Management Review 14 (4), 532-550.

Eisenhardt, K.M., Martin, J.A., 2000. Dynamic capabilities: what are they? Strategic Management Journal 21 (10-11), 1105-1121.

Finkelstein, S., 2006. Why smart executives fail: four case histories of how people learn the wrong lessons from history. Business History 48 (2), $153-170$.

Flynn, E., Kearns, T.C. 2011. Assessing the data: Filing trends in bankruptcy, 2007-2011. [online] Available from: http://www.justice.gov/sites/default/files/ ust/legacy/2012/04/30/abi_201111.pdf (accessed 17 September 2015).

Fredrickson, J.W., 1986. The strategic decision process and organizational structure. Academy of Management Review 11 (2), $280-297$.

Freeman, J., Carroll, G.R., Hannan, M.T., 1983. The liability of newness: age dependence in organizational death rates. American Sociological Review 48 (5), 692-710.

Gardiner, J.J., 2006. Transactional, transformational, and transcendent leadership: Metaphors mapping the evolution of the theory and practice of governance. Leadership Review 6 (Spring), 62-76.

Gassot, Y., Pouillot, D., Balcon, L., 2000. The merger and acquisition frenzy. Communications \& Strategies 38 (2), 159-195.

Gerard, G., Sleeth, R.G., Siders, M.A., 1999. Organizing culture: leader roles, behaviors, and reinforcement mechanisms. Journal of Business and Psychology $13(4), 545-560$

Ghemawat, P., 1991. Commitment: The Dynamic of Strategy. Free Press, New York.

Gilson, S.C., 1990. Bankruptcy, boards, banks, and blockholders: evidence on changes in corporate ownership and control when firms default. Journal of Financial Economics 27 (2), 355-387.

Ginsberg, A., Venkatraman, N., 1985. Contingency perspectives of organizational strategy: a critical review of the empirical research. Academy of Management Review 10 (3), 421-434

Grant, R.M., 1991. The Resource-based theory of competitive advantage: implications for strategy formulation. California Management Review 33 (3), 114-135.

Hamilton, E.A., 2006. An exploration of the relationship between loss of legitimacy and the sudden death of organizations. Group \& Organization Management 31 (3), 327-358.

Hannan, M.T., Carroll, G.R., 1992. Dynamics of Organizational Populations: Density, Legitimation, and Competition. Oxford University Press, Oxford, UK

Hannan, M.T., Freeman, J., 1977. The population ecology of organizations. American Journal of Sociology 82, 929-964.

Hannan, M.T., Freeman, J., 1984. Structural inertia and organizational change. American Sociological Review 49 (2), 149-164.

Hannan, M.T., Freeman, J., 1986. Where do organizational forms come from? Sociological Forum 1 (1), 50-72.

Hannan, M.T., Freeman, J., 1988. The ecology of organizational mortality: American Labor Unions. American Journal of Sociology 94 (1), 25-52.

Haveman, H.A., 1992. Between a rock and a hard place: organizational change and performance under conditions of fundamental environmental transformation. Administrative Science Quarterly 37 (1), 48-75.

Heracleous, L., Wirtz, J., Pangarkar, N., 2009. Flying High in a Competitive Industry: Secrets of the World's Leading Airline, Revised Edition. McGraw-Hill Asia, Singapore.

Hodgkinson, G.P., Wright, G., 2002. Confronting strategic inertia in a top management team: learning from failure. Organization Studies 23 (6), 949-977.

Ireland, R.D., Hitt, M.A., 2005. Achieving and maintaining strategic competitiveness in the 21st century: the role of strategic leadership. Academy of Management Executive $19(1), 63-77$.

Kelly, W., Amburgey, T.L., 1991. Organizational inertia and momentum: a dynamic model of strategic change. Academy of Management Journal 34 (3), 591-612.

Klepper, S., 1996. Entry, exit, growth, and innovation over the product life cycle. American Economic Review 86 (3), 560-581.

Leonard-Barton, D., 1992. Core capabilities and core rigidities: a paradox in managing new product development. Strategic Management Journal 13 (S1), $111-125$

Lieberman, M.B., 1990. Exit from declining industries: "shakeout" or "stakeout"? RAND Journal of Economics 21 (4), 538-554.

Lippman, S.A., Rumelt, R.P., 1983. Uncertain imitability: an analysis of interfirm differences in efficiency under competition. Bell Journal of Economics 13 , $418-438$.

Longenecker, C.O., Simonetti, J.L., 1999. Why organizations fail: The view from the front-line. Management Decision 37 (5/6), $503-513$.

Maccoby, M., 2000. Narcissistic leaders. Harvard Business Review 78, 69-77.

McGahan, A.M., Porter, M.E., 1997. How much does industry matter, really? Strategic Management Journal 18 (S1), 15-30.

Mellahi, K., 2005. The dynamics of boards of directors in failing organizations. Long Range Planning 38 (3), 261-279.

Mellahi, K., Wilkinson, A.J., 2004. Organizational failure: a critique of recent research and a proposed integrative framework. International Journal of Management Reviews 5/6 (1), 21-41.

Miles, R.E., Snow, C.C., 1984a. Fit, failure and the hall of fame. California Management Review 26 (3), 10-28.

Miles, R.E., Snow, C.C., 1984b. Designing strategic human resource systems. Organizational Dynamics 13 (1), 36-52.

Miles, R.E., Snow, C.C., Meyer, A.D., Coleman, H.J., Jr., 1978. Organizational strategy, structure, and process. Academy of Management Review 3 (3), 456-462.

Miles, R.E., Snow, C.C., Mathews, J.A., Miles, G., Coleman, H.J., Jr., 1997. Organizing in the knowledge age: anticipating the cellular form. Academy of Management Executive $11(4), 7-20$.

Miller, D., 1986. Configurations of strategy and structure: towards a synthesis. Strategic Management Journal 7 (3), $223-240$.

Miller, D., 1996. Configurations revisited. Strategic Management Journal 17 (7), 505-512.

Milliman, J., Von Glinow, M.A., Nathan, M., 1991. Organizational life cycles and strategic international human resource management in multinational companies: implications for congruence theory. Academy of Management Review 16 (2), 318-339.

Mintzberg, H., 1987. Crafting strategy. Harvard Business Review 65, 66-75.

Peteraf, M.A., 1993. The cornerstones of competitive advantage: a resource-based view. Strategic Management Journal 14 (3), $179-191$.

Porter, M.E., 1980. Competitive Strategy, Techniques for Analyzing Industries and Competitors. Free Press, New York.

Porter, M.E., 1985. Competitive Advantage: Creating and Sustaining Superior Performance. Free Press, New York.

Porter, M.E., 1996. What is strategy? Harvard Business Review 74, 61-78.

Powell, T.C., 1992. Organizational alignment as competitive advantage. Strategic Management Journal 13 (2), 119-134.

Prahalad, C.K., Hamel, G., 1990. The core competence of the corporation. Harvard Business Review 68 (3), 79-91.

Ramaswamy, K., Thomas, A.S., Litschert, R.J., 1994. Organizational performance in a regulated environment: the role of strategic orientation. Strategic Management Journal 15 (1), 63-74. 
Rindova, V.P., Kotha, S., 2001. Continuous “morphing”: competing through dynamic capabilities, form, and function. Academy of Management Journal 44 (6), 1263-1280.

Rosenthal, S.A., Pittinsky, T.L., 2006. Narcissistic leadership. Leadership Quarterly 17 (6), 617-633.

Rumelt, R.P., 1991. How much does industry matter? Strategic Management Journal 12 (3), 167-185.

Scholz, C., 1987. Corporate culture and strategy - The problem of strategic fit. Long Range Planning 20 (4), $78-84$.

Schuler, R.S., Jackson, S.E., 1987. Linking competitive strategies with human resource management practices. Academy of Management Executive 1 (3), 207-219.

Schumpeter, J.A., 2003 (1943). Capitalism, Socialism and Democracy. Routledge, London.

Stinchcombe, A.L., 1965. Social structures and organizations. In: March, J.G. (Ed.), Handbook of Organizations. Rand McNally, Chicago, pp. $142-193$.

Stoeberl, P.A., Parker, G.E., Joo, S., 1998. Relationship between organizational change and failure in the wine industry: an event history analysis. Journal of Management Studies 35 (4), 537-555.

Sutton, R.I., 1987. The process of organizational death: disbanding and reconnecting. Administrative Science Quarterly 32 (4), $542-569$.

Teece, D.J., Pisano, G., Shuen, A., 1997. Dynamic capabilities and strategic management. Strategic Management Journal 18, $509-533$.

van Witteloostuijn, A., 1998. Bridging behavioral and economic theories of decline: organizational inertia, strategic competition, and failure. Management Science 44 (4), 501-521.

Venkatraman, N., 1989. The concept of fit in strategy research: toward verbal and statistical correspondence. Academy of Management Review 14 (3), 423-444.

Venkatraman, N., Camillus, J.C., 1984. Exploring the concept of “fit” in strategic management. Academy of Management Review 9 (3), 513-525.

Voelpel, S.C., Leibold, M., Tekie, E.B., 2006. Managing purposeful organizational misfit: exploring the nature of industry and organizational misfit to enable strategic change. Journal of Change Management 6 (3), 257-276.

Waterman, R.H., Jr., Peters, T.J., Phillips, J.R., 1980. Structure is not organization. Business Horizons 23 (3), 14-26.

Wernerfelt, B., 1984. A resource-based view of the firm. Strategic Management Journal 5 (2), 171-180.

Wirtz, J., Heracleous, L., Pangarkar, N., 2008. Managing human resources for service excellence and cost effectiveness at singapore airlines. Managing Service Quality 18, 4-19.

Wright, P.M., Snell, S.A., 1998. Toward a unifying framework for exploring fit and flexibility in strategic human resource management. Academy of Management Review 23 (4), 756-772.

Yin, R.K., 2008. Case Study Research: Design and Methodology. Sage Publications, Thousand Oaks.

Zajac, E.J., Kraatz, M.S., Bresser, R.K.F., 2000. Modeling the dynamics of strategic fit: a normative approach to strategic change. Strategic Management Journal $21(4), 429-453$.

Zammuto, R.F., Cameron, K., 1985. Environmental decline and organizational response. Research in organizational behavior 7 (1), $223-262$.

\section{Biographies}

Loizos Heracleous is Professor of Strategy and Organization at the Warwick Business School, and Head of the Strategy Group. He received his PhD from the Judge Business School at Cambridge University, and his research has been published in the Academy of Management Journal, Academy of Management Review, Strategic Management Journal, MISQ Harvard Business Review, MIT Sloan Management Review and other outlets. He has received several research and teaching awards, including three awards from the Academy of Management (U.S.).E-mail: loizos.heracleous@wbs.ac.uk

Katrin Werres is an independent researcher who completed her MSc degree at the Warwick Business School. She finished in the top 3\% of her class, and now works for Google in Online Media, specializing in Google’s German-speaking markets. E-mail: katrin.werres@gmail.com 